\title{
The Siete Partidas: A Repository of Medieval Military and Tactical Instruction
}

\author{
Jürg Gassmann, \\ Independent researcher
}

\begin{abstract}
Specifically military literature that deals with matters such as battlefield formations for infantry and cavalry, the appointment of senior officers, or the rules for spoils, is rare for Europe in the period before the fifteenth century. One curious and not extensively studied exception is the second half of Part II of the Siete Partidas, compiled in the mid-thirteenth century for the Castilian king Alfonso X, el sabio (the Wise). The Siete Partidas constituted the code of law for Castile and set out practical solutions for these subject matters within the contemporary military doctrine and the ideals of chivalry.

In reviewing medieval literature, the question as to the document's sources inevitably arises, especially the reuse of classical literature. While the rules on spoils have precedent in the municipal fueros, it is difficult to identify predecessors for the tactical elements, both in style and substance.

Overall, the Siete Partidas offers a unique insight into the mechanics of leadership and the battlefield formations of the High Middle Ages, as well as the crucial function of spoils as a source of status-compatible income for the knightly estate and lower nobility, thus adding depth and texture to this littlestudied yet essential aspect of medieval military, economic, and political organisation.
\end{abstract}

Keywords - Siete Partidas, Middle Ages, Medieval Military, Medieval Tactics, Medieval Warfare, Medieval Law, Chivalry, Castile, Vegetius, pulcher tractatus

\section{INTRODUCTION}

\section{I.1. European Military Literature in the High Middle Ages}

There is not much original, specifically military literature relating to the organisation and behaviour of forces on the battlefield for Catholic Europe in the High Middle Ages. Texts from antiquity survived - Vegetius' de re militari was extensively copied, translated, and likely used throughout the time; also known were texts such as Sextus Julius Frontinus' anecdotal Strategemata. ${ }^{1}$ An odd exception is the anonymous, probably late thirteenth-century Italian pulcher tractatus de materia belli, which quotes extensively from

\footnotetext{
${ }^{1}$ Hosler, 'Medieval Military Strategy', pp. 191-93; Nicholson, Medieval Warfare, pp. 13-18; Taylor, 'English Writings', pp. 66-68. Allmand, Vegetius, pp. 96-104, finds Vegetian ideas reflected in Partida II. For the use of Vegetius and original military literature in Castile see García, 'didáctica militar', pp. 271-75; Etxeberria, 'liderazgo militar’, pp. 643-44, 647.
} 
Vegetius, but also contains original passages. ${ }^{2}$ Until true military writing appears as a genre towards the end of the fourteenth century, military-related facts and thinking are predominantly found in legal documents, chronicles, reality-affine hagiographies of military leaders, and outright fiction such as the various sagas, chansons de geste, and courtly poetry. Authors contributing original texts on military matters are rare, but they do exist, for example Gerald of Wales (c.1146-c.1223) or John of Salisbury (c.11101180), but their focus is strategy, not the minutiae of command and formations. ${ }^{3}$

Original literature dedicated specifically to military matters burgeons from the late fourteenth century onwards; the witnesses, which include names such as Giovanni da Legnano, Christine de Pizan, Honoré Bouvet, Geoffroi de Charny, or Jean de Bueil, increasingly write in the vernacular rather than in Latin. The focus of this newly developing genre is on a complex of issues including just war, legitimate violence, acceptable profiteering, leadership, and honourable conduct (sometimes encapsulated by the term 'chivalry'). ${ }^{4}$

\section{I.2. The Siete Partidas}

A code of law is unusual in the context of military tactical manuals, yet the term is not out of place for certain chapters of the Siete Partidas (the Seven Parts or Divisions), the common term for legislation compiled in the mid-thirteenth century by a committee of jurists reporting to Alfonso X, King of Castile, referred to as el sabio (the Wise). Composed in already fairly modern Spanish, it covers the seven subjects: church, government, law, family, commerce and the sea (Parts IV and V), and underworlds (Parts VI and VII deal with the dead, criminal, and marginalised). Each Partida is divided into titles or chapters, and each title contains several laws. ${ }^{5}$

The laws are written in essayistic, discursive text, not in the question/answer style of Justinian's Digests, nor in the narrative legalese of the late Roman Novellae, nor in the terse if/then rhythm of the leges barbarorum or modern legislation, but also without the

2 Pulcher tractatus; Pichler's discussion on the dating on pp. 14-19; Pichler finds that the anonymous author of the pulcher tractatus, probably of North Italian origin, was an experienced officer with good knowledge of Vegetius, pragmatically selecting those Vegetius passages that suited his intentions, and supplementing with own experience and analysis. Also in Allmand, Vegetius, p. 232.

${ }^{3}$ Hosler, 'Medieval Military Strategy', pp. 193-202; Çeçen, Interpreting Warfare and Knighthood, pp. 118-19 and passim; Allmand, Vegetius, pp. 88-91; Taylor, 'English Writings', p. 64. Especially Verbruggen argues that medieval commanders invested considerable intellectual effort into warfare, tactics and strategy: Verbruggen, Warfare, pp. 204-350.

${ }^{4}$ On this complex, see Çeçen, Interpreting Warfare and Knighthood; also Nicholson, Medieval Warfare, pp. 18-19; Verbruggen, Warfare, p. 288; Taylor, 'English Writings,' pp. 69-72 and passim; Delbrück, Kriegskunst, pp. 746-48; Etxeberria, 'liderazgo militar,' pp. 643-44.

5 Siete Partidas I (O’Callaghan), pp. xxx-xl. 
structured didactics of the Institutiones or the Decretum Gratiani. ${ }^{6}$ By virtue of their style, the text provides a practical and sensible guide to government, regardless of its format as legislation. The Siete Partidas was of importance to the laws of Castile, then Spain, and then the Spanish colonies, influencing also the laws of formerly Spanish US States such as Louisiana, Texas, Arizona, and California. ${ }^{7}$ Though largely superseded by the codifications based on the Napoleonic models, the principles set out in the Siete Partidas still echo through Iberian and related legal systems.

Of interest here is the second Partida, dealing with medieval government. The Spanish text used is the redaction issued in print by Gregorio Lopez in 1555; Spanish legal historians regard it as the most useful edition of the texts. ${ }^{8}$

This article focuses on selected passages of Titles XXI-XXX that deal with land battles (leaving out Title XXIV, which deals with naval warfare). I shall review the content of the military provisions, consider them in the context of what is known of the tactics of the time, and analyse whether they had any discernible influence on later military literature. The focus here is on three areas: the appointment of senior officers, battlefield formations for infantry and cavalry, and the rules on spoils. The Siete Partidas deals with a broader palette, but available space required a limitation, and it is proposed that the provisions reviewed offer additional insights into aspects of medieval battles.

\section{I.3. Translations}

English passages from the Siete Partidas are taken from Scott's translation in Burns; other translations are mine unless otherwise indicated. ${ }^{9}$ In transcribing, I have resolved the ligatures in Gregorio Lopez's typography, but otherwise quotations are given in the spelling used in the source referenced.

${ }^{6}$ Panateri, 'Adaptar y sobrevivir', with notes on the early development of the Siete Partidas.

7 Siete Partidas I (Burns), pp. xii and xix-xxix.

${ }^{8}$ In the context of this article, it was not possible to review a history of the various versions; for further reading on the general development, see Panateri, Discurso del rey, pp. 44-47; idem, 'Adaptar y sobrevivir', and the notes by O'Callaghan on the history (pp. xxx-xl) and by Craddock on the bibliography (pp. xli-xlviii) in Siete Partidas I. Lopez' edition, albeit the one from 1443, is also the basis for Scott's translation (Siete Partidas I (Burns), pp. xii-xiii). Though the text itself is in Spanish, Lopez' gloss is in Latin. There is one further comprehensive edition, compiled by the Spanish Royal Print in 1807, but no more recent effort; see Panateri, op. cit.

9 Siete Partidas II (Burns); I have occasionally departed from Scott's translations, and indicated where I have done so. In that context, I am indebted to Manuel Valle Ortiz for his guidance, though the emphases and choices, and any related errors, remain my own. 


\section{THE PRINCIPLES OF WARFARE}

\section{II.1. Knights, Senior Officers, and Commanding Officers}

Title XXI (comprising twenty-five laws) is preoccupied with the selection, creation, and behaviour of knights (caualleros); Title XXII (comprising seven laws) then deals with the selection, creation, and powers of senior officers (adalides). It is not necessary that a senior officer be a knight, but he should be selected for his intelligence (or learning/knowledge), strength, good natural prudence, and loyalty (sabiduria, esfuerço, buen seso natural, lealtad). ${ }^{10}$

Adalides should be appointed on the recommendation of twelve wise commanders, and be given clothes, a horse, and arms. ${ }^{11}$ During his promotion, a commander of knights should be raised on a shield, where he should strike his sword in the shape of a cross on all four points of the compass, and be given a banner. Once appointed, he has the rank of knight; he will then have the right to reprimand knights and omes honrrados ('men of distinguishing rank') under his command, and physically chastise light cavalry troopers and foot soldiers. ${ }^{12}$

The ceremony has a two-fold purpose: it demonstrates respect toward the commander for the responsibility he is assuming and also emphasises, to his men, that the commander must be obeyed. The commander is given both the authority and the responsibility to arrange for supplies, to post sentries and send out patrols, to organise foraging, to appoint subalterns, to allocate spoils, and to lead his troops into action. A commander who is remiss in his duties may be punished via his person or his property. ${ }^{13}$

${ }^{10}$ Las Siete Partidas, 2:22:1, pp. 76v-77r; Siete Partidas II (Burns), pp. 433-434; Powers, Society Organized for War, pp. 151-52. The advice contained in this law regarding scouting, protection of logistics and lines of communication, as well as supplies, are closest to Vegetius. It is tempting to compare the four virtues to Fiore de' Liberi's allegorical animals prudentia, fortitudo, celeritas and audatia in his 'Seven Swords' diagram (early fifteenth century): Gassmann, Gassmann, and Le Coultre, 'Fighting with the Longsword', pp. 123-26.

11 Las Siete Partidas 2:22:2, p. 77v; Siete Partidas II (Burns), pp. 434-435; Las Siete Partidas 2:22:3, p. 77v; Siete Partidas II (Burns), p. 435.

12 Siete Partidas II (Burns), p. 435; Las Siete Partidas 2:22:3, p. 77v: 'ha poder de cabdillar los omes honrrados, e a los caualleros, por palabra, e a los almogauares de cauallo, e a los peones de fecho feriendo los e castigando los...'; Lourie, 'Society Organized for War', p. 71.

${ }^{13}$ Las Siete Partidas 2:22:4, pp. 77v-78r; Siete Partidas II (Burns), p. 436. 
Title XXII promises to be about 'Commanders, Light Cavalry, and Foot Soldiers'. ${ }^{14}$ There is not much on the almogavares, the light cavalry, but the following passage in Law 6 is interesting:

Et maguer alguno fuesse a tal, que meresciesse ser adalid, non lo puede ser, amnos de ser algun tiempo, almogauar de cauallo. E segun dixeron los antiguos, las cosas que han de yr a bien, siempre han de yr, e de sober de vn grado a otro mejor. Assi como fazen del buen peon, buen almocaden, et del buen almocaden, buen almogauar de cauallo, e de aquel, el buen adalid. ${ }^{15}$

A rise in rank is described very clearly, and unlike modern military practice, the progression cuts across functions: the ordinary foot soldier is promoted to command an infantry unit, from there to light cavalry trooper, to finally become an officer with the rank of knight, with power over nobility and other knights. ${ }^{16}$

The ceremony for promotion of the infantry unit commander set out in Law 6 is similar to the one described for the senior officers, but less elaborate. Instead of being raised on his shield, he stands on the shafts of lances, and the protocol lacks the elements of dubbing inherent in the adalid's appointment. ${ }^{17}$

The Partida suggests that promotion is open to the capable, regardless of social position. Whether that was the reality is hard to determine and a prosopographical investigation would be interesting. Writing of the situation two centuries later, Etxeberria finds that important military commands were reserved for the nobility, but capability and experience were determinative among the eligible. ${ }^{18}$ The Partidas was written not long after the military heyday of Iberia's city militia in the twelfth and thirteenth centuries, so social permeability to military commands may have been more realistic, but the militias'

${ }^{14}$ Las Siete Partidas 2:22, p. 76v: 'De los adalides, e almogauares, e de los peones'; Siete Partidas II (Burns), p. 433.

${ }^{15}$ Las Siete Partidas 2:22:6, p. 78r: 'Even if a party has qualifications which would entitle him to be an adalid [senior officer], he cannot become one, unless he has served a certain time as a light horseman; and as the ancients said whatever goes well should always progress and rise from one rank to a greater one; so a good almocaden [infantry unit commander] is made out of a good foot soldier, and a good light horsemen [sic] out of a good almocaden, and a good adalid out of him'. Siete Partidas II (Burns), p. 437; Powers, Society Organized for War, p. 152.

16 Lourie, 'Society Organized for War', p. 71; non-noble mounted fighters (caballeros villanos) were not unusual - ibid., pp. 55-56.

${ }^{17}$ Lourie, 'Society Organized for War', p. 71.

${ }^{18}$ Etxeberria, 'liderazgo militar,' pp. 654-55. The pulcher tractatus avoids references to knightly heroics or noble fame, but emphasises intelligence, preparation, risk avoidance, and experience, see p. 35. 
relevance to the warfare of the Christian Iberian kingdoms had receded by the fifteenth century. ${ }^{19}$

\section{II.2. Light Cavalry}

The Partida unfortunately does not elaborate on the light cavalry almogaveres, their composition, equipment, or tactical uses - though Title XXII Law 4 suggests that their role was foraging and patrolling. ${ }^{20}$ It would be interesting to speculate that we are seeing an early reference to the ginetes, the light cavalry units copied from the Moroccan Berber cavalry imported by the Emir of Granada, and which were to feature prominently in the border actions between Granada and Castile in the fourteenth century; on the other hand, light cavalry - especially in the form of mounted municipal levies - were a perennial component in Iberian armies. ${ }^{21}$

\section{II.3. Signals}

In warfare, signals are an important means by which commanders communicate with their troops. In the noise of battle, mere voice is insufficient to communicate effectively, so commanders use visual signs or sounds which, due to their pitch or volume, carry further and overcome the general level of noise. ${ }^{22}$

The Siete Partidas does not deal with sound signals, but Laws 12-15 of Title XXIII specify not only the different types of banners that may be used, but also those which must be used, where each type of banner indicates the size of the respective unit. At the same time, only the correct, permitted banners may be shown in order to avoid visual clutter and prevent the dilution of the information conveyed by the banners. ${ }^{23}$

\section{II.4. Other General Principles of Warfare}

Title XXIII is lengthy, comprising thirty laws, and deals with general principles of warfare: supplies and logistics, foraging, field tactics, sieges, organisation of the army on the march, reconnaissance, set pieces such as ambushes, and so on. To a very large extent, the subject matter finds its parallels in Vegetius, but it is not lifted from Vegetius. While

${ }_{19}$ Powers, Society Organized for War, pp. 71, 152.

${ }^{20}$ Las Siete Partidas 2:22:4, p. 77v; Siete Partidas II (Burns), p. 436.

${ }^{21}$ Rincón, 'La monta a la gineta; Fallows, Jousting, pp. 273-84; Powers, Society Organized for War, pp. 97-103, 132-133, and passim; Lourie, 'Society Organized for War', p. 58.

22 The pulcher tractatus expands on Vegetius' passages regarding sound signals, banners, and other means - cap. 30, 31 / pp. 60-61. In the Templar Rule, the marshal bears the banner, and is tightly protected; he is followed by the commander of the knights, with a furled banner - this must be unfurled if, but only if, the marshal meets with misadventure: Règle du Temple, Rules 164-165 / pp. 125-26. Bennett, 'Cavalry Charge', pp. 183-84.

23 See also Section II.1. The Templar Rule also does not refer to sound signals. 
all of these issues deserve closer investigation for their own merit, space does not permit a comprehensive treatment.

Not all issues dealt with here, however, are found in Vegetius; the discussions on the types of war (just war, unjust war, civil war, internecine war) in the introduction to the title and Law 1, for example, are peculiar to medieval literature. ${ }^{24}$ Similarly, the discussion on who should be appointed general is not found in Vegetius. According to the Siete Partidas, a general (cabdillo) should have one of three qualities, either one of which justifies his appointment: he should have lineage (linaje), or power (poderio), or wisdom (sabiduria), with the latter being the most meritorious. ${ }^{25}$ However, these issues lie outside the battlefield, and so outside the focus of this article. Also not found in Vegetius are the battlefield formations.

\section{BATTLEFIELD FORMATIONS}

If general military literature is rare in the mid-thirteenth century, then details on the battlefield formations of the time are rarer still. The Roman literature that has survived - especially Vegetius - does not deal with formations, and the literature that does, like Asclepiodotus, Arrian, or Aelianus, was not in circulation in Latin Europe until the sixteenth century. ${ }^{26}$ This is not the place to discuss why this may have been so, but the fact remains that the Siete Partidas is a rare source for specifics on battlefield formations. ${ }^{27}$

${ }^{24}$ Las Siete Partidas 2:23:1, p. 78v - and merits several pages of gloss by Lopez; Siete Partidas II (Burns), pp. 439-40.

25 Las Siete Partidas 2:23:4, p. 84r; Siete Partidas II (Burns), p. 441.

26 Vegetius, de re militari, Book III, Cap XX (pp. 77-80) does deal with formations, but the focus here is on arrangement of the battle line and predominantly infantry manoeuvring out of the battle line, not on specifics of the shape of infantry or cavalry unit formations. In Book I, Cap XXVI (pp. 20-21), Vegetius deals with infantry evolutions, mainly proceeding from one to two and four ranks and back again, and also does refer to the infantry forming a wedge ('in trigonum (quem cuneum vocant)'), a 'useful formation.' The Vegetius imprint referenced here includes Frontinus' Strategemata, Aelianus Tacticus' De instruendis aciebus and Modestus' De vocabulis rei militaris. Powers, Society Organized for War, pp. 155-56, refers to the formations as original to the Partidas and not adumbrated in the militia fueros, though he believes them derived from Vegetius, which I do not see for the reasons given; Çeçen, Warfare, pp. 31-36 and passim; Stadter, 'Ars Tactica of Arrian', pp. 117-19.

27 Despite their sometimes micro-managing details on Templars' behaviour, and injunctions around brothers' conduct on the march and in action, the Règle du Temple is silent on the actual formations employed. The pulcher tractatus in its treatment of the battle line draws on Vegetius, but reinterprets the passages; there is no commonality with the Partidas. The sources for high and late medieval battlefield formations are reviewed and analysed in a separate forthcoming article. 


\section{III.1. Formation Types}

The relevant discussion is contained in Title XXIII, Law 16; there is no systematic differentiation within foot formations and mounted formations, but the text allows for the distinction between the two types.

Law 16 lists the following formations:

- Haz, literally a bunch, compare Latin fasces, but here meant as 'line'; compare French la baie, a hedge. Scott translates it as 'rank'.

- Muela, millstone, a rounded square (carro redondo).

- Cuneo, wedge, see below.

- Muro, wall, a dense, square formation.

- Cerca or corral, a hollow, enclosure-like formation, also see below.

- Acitara, a wing, intended to protect the flanks, and to outflank an opposing formation.

- Tropel, literally a herd, translated by Scott as 'troop', simply refers to an assemblage of men, without defining their formation or number. ${ }^{28}$

The commandants are instructed to familiarise themselves with these formations, so that they themselves can put them to use, and to know which ones to apply against a given enemy formation. ${ }^{29}$

From the text, the millstone, the wall, and the corral are intended as infantry formations; the advantage of the millstone is that it has no flank, the entire formation makes a front against the enemy.

The muro and corral are described as follows:

E el muro fizieron para quando viessen los enemigos, que pudiessen meter todo lo suyo en medio para tener lo en saluo, porque non gelo pusiessen desbaratar, nin forçar. Esto vsauan, quando los Reyes auian a auer batalla los vnos con otros, que dexaua los vnos para guarder la compaña del rastro de la hueste, assi como sobredicho es, e los otros yuan a lidiar. E corral, o cerca, fazian para guardar sus Reyes, que estouiessen en saluo. E esto fazian, de omes de pie, que los parauan en tres hazes, unos empos de otros, et atauan los a los pies, por que non se pudiessen yr, e fazian les tener los cuentos de las lanças fincados en tierra, e las cuchillas endereçadas contra los enemigos, e ponian cabe ellos piedras, o dardos, o ballestas, o arcos con que pudiessen tirar et defender se de lueñe. E esto fazian por tener

\footnotetext{
${ }^{28}$ For these formations, see Las Siete Partidas 2:23:16, pp. 86v-87r; Siete Partidas II (Burns), pp. 44850; Martinez, 'l'étude du geste guerrier', pp. 63-64.

${ }^{29}$ Las Siete Partidas 2:23:16, p. 87r; Siete Partidas II (Burns), p. 450.
} 
honrrado su Señor, que los enemigos non pudiessen llegar a el; ni le fazer mal, ... ${ }^{30}$

Two of the formations, the haz tendida and the cuneo, are explicitly mentioned as meant for cavalry: 'las hazes tendidas, fizieron, por que paresciessen mejor en ellas los caualleros, et se muestran por mas delo que son, que es cosa que faze a la mala gente tomar mayor espanto, e vencer se mas ayna'. 31 The formation also allows an envelopment of the opposing formation. ${ }^{32}$

The 'wedge' (cuneo) is also an explicitly cavalry formation, and its structure and purpose are likewise specified:

E la otra manera que llaman cuneo fue sacada, por que quando las hazes delos enemigos fuessen fuertes et espessas que las podiessen romper, e departir, e vencer, mas ayna. Ca desta guise vencen los pocos a los muchos. E deue ser fecha desta guisa, poniendo primeramente delante tres caualleros, e a las espaldas dellos seys, et empos de los seys, doze, e empos destos, veynte e quatro, et assi doblando los, e cresciendolos toda via, segun fuere la compaña. Pero si la gente fuesse poca, bien podrian fazer la delantera de vno, e de si doblar de dos e de quatro, segund la manera que desuso diximos. ${ }^{33}$

${ }^{30}$ Las Siete Partidas, 2:23:16 (p. 87r): 'They devised the wall so that when they caught sight of the
enemy they could put all their baggage in its centre, so that it could not be destroyed or taken by
force. They made use of this formation when kings engaged in battle with one another, and left
some to guard the baggage train of the army as above stated, while the others went into action.
They formed a corral, or enclosure, to protect their kings, so that they might remain in safety. They
formed it with infantry, which was drawn up in three rows, one behind the other, and they tied
their feet together so that they might not be able to run away, and made them hold the butts of
their lances resting on the ground, with the blades pointed directly towards the enemy, and placed
within their reach stones, darts, crossbows, or bows, by means of which they could shoot and
defend themselves at a distance. They did this to preserve the honour of their lord...' Siete Partidas
II (Burns), p. 449. Also mentioned in Delbrück, Kriegskunst, pp. 744-45. 31 Siete Partidas II (Burns), p. 449: 'They instituted extended ranks in order that the knights might make a better appearance, and seem to be more in number than they really were, which is something that causes ill-disposed people to experience greater fear and to be more readily overcome'; Las Siete Partidas 2:23:16, p. 87r.

32 Las Siete Partidas 2:23:16, p. 87r; Lourie, 'Society Organized for War', p. 70.

${ }^{33}$ Las Siete Partidas 2:23:16 (p. 87r): ' $\ldots$ and the other body, called a wedge, was invented, in order that when the ranks of the enemy were strong and thick they could break and divide them, and conquer them more readily, for, by this means, few could overcome many. The wedge should be formed in the following way, namely; by first placing three knights in front, and behind them six, and in the rear of the six twelve, and behind them twenty-four, and thus doubling them and increasing their number constantly, according to the size of the division; but where the soldiers 
The formations specific to the infantry come across as static, while those for the cavalry imply movement. Another formation that implies movement, the acitara or 'wing', could refer to infantry or cavalry.

In general, cavalry should take care, when attacking infantry, not to charge entrenched enemies, or those on high or broken ground, but should draw them out into the open plain where the cavalry's advantages can be brought to bear. ${ }^{34}$

\section{III.2. Comparison with Other Sources}

Most of the battle formations found in the Siete Partidas - for example line or square are so basic and generic that their appearances in later texts or uses on the battlefield do not justify an argument about sources or a continuing influence of the Siete Partidas.

A possible exception, however, is in Giles of Rome's de regimine principum, written probably between 1277 and 1281, so not long after - if not contemporary with - the Siete Partidas. In the final part, on warfare, he first refers to Vegetius' injunctions to practice evolutions, but also to the circle, triangle (wedge), and square formations, formations which (other than the wedge) do not appear in Vegetius. Giles' text is an odd mix; some parts are theoretical and surely impractical (and different from the instructions in the Siete Partidas), such as when he says that a wedge is easily formed by drawing a diagonal across the square and remarrying the halves. ${ }^{35}$ On the other hand, his rationales for the uses of the formations are tactically more accurate, echoing the Siete Partidas, but are not copied from it.

The muela appears to be the Flemish foot formation used successfully against the French at the battle of Arques (1303), as described in the Annales Gandenses, and called therein a corona ('circlet' or 'crown'). In said circumstance, the Flemish were unable to field cavalry, so an infantry formation that could not be outflanked by the strong French cavalry made tactical sense. ${ }^{36}$

References to a line cavalry formation, and the risk of envelopment, can be found with William the Breton relating the arrangement of the battleline for Bouvines (1215), which predates the Siete Partidas, where the French cavalry is told 'Campus amplus est; extendite vos per campum directe, ne hostes vos intercludant'. ${ }^{37}$ Similarly, in Jan van

were few in number, they could begin with one, and then double the numbers, as above stated.' Siete Partidas II (Burns), p. 449; Lourie, 'Society Organized for War', p. 70.

${ }^{34}$ Las Siete Partidas 2:23:7, p. 85r; Siete Partidas II (Burns), p. 443.

35 Giles of Rome/Aegidius Romanus, De regimine principum, Book III, Part 3, Chapter 12 (unpaginated); Delbrück, Kriegskunst, pp. 742-43; Etxeberria, 'liderazgo militar,' p. 644.

36 Annales Gandenses, p. 575; DeVries, Infantry Warfare, pp. 27-31.

37 'The battlefield is large; extend yourselves across the field in a straight line, so that the enemy will not outflank you' - William the Breton, Gesta Philippi Augusti, pp. 276-77; Delbrück, Kriegskunst, p. 332; France, Western Warfare, pp. 170-71. 
Heelu's verse epic on the 1288 battle of Worringen (or Woeringen), one of the formations discussed is the line, though in this specific case an alternative tactic proved successful. In van Heelu, the line formation is referred to as one being used in a tournament context. ${ }^{38}$

The Siete Partidas' wedge (cuneo) is quite specific, and specifically a cavalry formation; it also hearkens back to formations described in the manuals of antiquity. But the 'wedge' is rarely mentioned in medieval literature, and even where an author uses the Latin word cuneus, for instance, the context regularly shows that the author merely intended to refer to a dense array, not a wedge-shaped, battlefield attack formation. ${ }^{39}$

An unequivocal reference to a cavalry wedge, however, is found in Erhard Schürstab's description of the battle at Pillenreuth in 1450, where Nuremberg's cavalry defeated the cavalry of Albrecht Achilles, Margrave of Brandenburg. ${ }^{40}$ Schürstab painstakingly describes the structure of the formation; if it had been a common military feature he could have contented himself with the statement that the respective cavalries were set up in a wedge, and in any event, the structure of Schürstab's wedge is different from the one described in the Siete Partidas.

Fernão Lopes' description of the battle of Aljubarrota (1385), on the other hand, is intriguing. ${ }^{41}$ The victory is seminal for Portuguese national identity, and it is common ground that it pitted a numerically overwhelming Castilian attacker against a small Portuguese force reinforced by English longbowmen. ${ }^{42}$ The interesting feature of the Portuguese disposition - for the purposes of this article - is the following formation around the king:

Traz esta reguarda havia um espaçoso curral onde estava a carriagem, s. pagens, cavallos, azemulas, mantimento, gente de serventia e todas outras cousas que mister fazem pera a ordenança de uma hoste, e estes eram todos cercados de homens de pé e bésteiros, de geito que

\footnotetext{
38 Van Heelu, Woeringen, pp. xvii-xviii, pp. 185-6 / lines 4,918-4,953; Verbruggen, Warfare, pp. 36, 86, 266-67; Delbrück, Kriegskunst, p. 332.

39 Delbrück, Kriegskunst, p. 755.

40 Schürstab, Erster Markgräflicher Krieg, pp. 96-115; Delbrück, Kriegskunst, pp. 325-32.

41 There are three other narratives on the battle: Froissart, Pero Lopez de Ayala, and the anonymous Crónica do Condestabre; in all four narratives, the Portuguese success is attributed to field entrenchments which nullified the Castilian heavy cavalry advantage and allowed the Portuguese and allied infantry to inflict a heavy defeat, but the formation described by Lopes is not mentioned in the three others. See Guimarães, 'Aljubarrota', and references.
}

42 Guimarães, 'Aljubarrota', pp. 121-28. 
nas espaldas da reguarda e em esta carriage nenhum não podia topar pera fazer damno, que todo não achasse apercibido. ${ }^{43}$

This precisely reflects the description of the muro and corral in the Siete Partidas, though there is no mention of the men being tied together.

Lopes wrote at least a century after the compilation of the Siete Partidas, and he wrote for the Portuguese defenders, while the Siete Partidas was the governing text for the Castilian attackers. Nevertheless, the Siete Partidas was known in Portugal, and partial Portuguese versions do survive, including passages from the second Partida, though the chapters discussed in this article are not evident in the witnesses. ${ }^{44}$ Still, the Siete Partidas would have been known, and either way, it is not fanciful to see a common Iberian tradition in both the Siete Partidas and Lopes' narrative, which remains as an artefact even if Lopes' story is based on verisimilitude and traditions of wise military command rather than fact. Of course, the concept of a baggage train protected by troops is a regular feature of battle narratives, but both the explicit mention of the hollow square and the congruence in the vocabulary, to my mind, argue that more than coincidence is at play.

\section{BOOTY, RANSOMS, AND SPOILS}

\section{IV.1. Noble Largesse and Sources of Income}

A distinctive mark of nobility was largesse - the liberality of the knight is a staple of the chansons de geste and courtly literature in general. ${ }^{45}$ At the same time, medieval nobility were severely restricted in the sources of income that were status-compatible; pedestrian activities such as trades or crafts involving manual labour were off-limits, nor could they be trader 'boxwallahs' or engage in manufacturing, never mind how lucrative. Statuscompatible income could be derived from rents from fiefs, principally from land, which tended to be fairly stable but meagre. Short of marrying into it, though, 'real money' could only be made from fighting by winning booty, ransoms, or spoils. ${ }^{46}$

\footnotetext{
${ }^{43}$ Lopes, Chronica, p. 147: 'In the rear, there was a spacious hollow formation with the baggage, squires, horses, mules, supplies, servants and all other things that a lord keeps to maintain a host, and all these were surrounded by infantrymen and crossbowmen, in such a way that at the rear of this baggage it was not possible to inflict damage without such being noticed by everyone'. I am grateful to Nuno Valverde for guidance with the language.

44 Domingues, 'As Sete Partidas em Portugal', pp. 8-9; Siete Partidas I (Craddock), p. xlii.

45 Bumke, Höfische Kultur, pp. 314-17 and 369-71, referring to Hartmann von Aue's Erec, also Keen, Chivalry, pp. 154-55; Kaeuper, Chivalry, pp. 193-98, 282.

46 Price, 'Yron \& Stele', p. 165; Verbruggen, Warfare, pp. 49-51; Keen, Chivalry, p. 154.
} 
The Siete Partidas spends a remarkable amount of space on this issue proper in Titles XXVI (Spoils of War - thirty-four laws) and XXVII (War Prizes - ten laws), and even more if one takes into account the related issues of reparations (Title XXV - five laws), captives and captive property (Title XXIX - twelve laws), and redemption of captives (Title XXX - three laws). ${ }^{47}$

\section{IV.2. Rules on Spoils}

Title XXVI addresses the following issues:

- Premature looting - Laws 1-3 emphasise that looting must not commence until the victory is truly won; too often a supposedly victorious army focuses on pillage and the inevitable squabbles, thus rendering itself vulnerable to a resurgent enemy. In the same vein, all who participated in the success should share in it, especially any detachment sent to pursue and harass the fleeing enemy, but also sentries, scouts, and spies; they should not suffer any detriment from being absent from the looting or the battlefield itself.

- Prohibitions from booty-taking - In the context of insurrections, the taking of booty is prohibited, as is the taking of prisoners for ransom or sale, or the mutilation of prisoners or the dead (Laws 16 and 17). The Siete Partidas is concerned about maintaining civic peace, and not complicating an already tense and fraught situation by allowing the populace to be despoiled, or to inject an opportunity for gain at the cost of another subject, which would only generate further grievances that might make re-establishing peace and reconciliation more difficult.

- King's share - The king is entitled to a share of $20 \%$ of the booty consisting of moveable property; the immovable property - towns, castles, palaces, capital ships - as well as the captured enemy commander, his wife or wives, and children, or other high-value captives, all belonged to the king by right of prerogative. ${ }^{48}$ If the king had personally provided the supplies for a raid, then $50 \%$ of the proceeds were his.

\footnotetext{
${ }^{47}$ The Decretum Gratiani in Distinctio I, C.X: 'Quid sit ius militare' says: 'ius militare est ... praedae decisio, et pro personarum qualitatibus et laboribus iusta diuisio, ac principis portio’ [military law includes ... decision on the booty, the division in accordance with individuals' standing and performance, and the prince's share], p. 5. Powers, Society Organized for War, on pp. 162-187 devotes a full chapter to the municipalities' rules for the militias' booty distribution, which clearly supplied precedent to the rules contained in the Siete Partidas. Settia points out that in the Cantar de mio Cid (late twelfth/thirteenth century), Rodrigo Díaz requires a careful valuation of the spoils and fair distribution, and claims a fifth for himself: Settia, Rapine, p. 68. On the English practice in the fourteenth century, see Ayton, Knights and Warhorses, pp. 127-37.

48 Las Siete Partidas 2:26:4 (p. 95v); Siete Partidas II (Burns), p. 476; the level of 20\% has precedent in Moorish practice on the Peninsula and in the twelfth-century Christian municipal militia charters, but in the latter is awarded after the compensations have been paid: Powers, Society Organized for War, pp. 172-174. 20\% appears modest compared to the one third that seems to have
} 
The regular 20\% royal cut applies to booty won in all manner of altercations, whether 'en fazienda, o en lid, o en caualgada, o en torneo, o en espolonada, o en algara, o en celada [...]'.49 The cut is of the gross movable booty, before deducting the compensations for wounds, restor (the restaurum or restauro equorum, the compensation for horses lost in service), and other costs.

- Exemptions from the king's share - It is not surprising that a royal collection of laws would seek to ensure the king's cut, but some situations expressly exclude it; these are mentioned in Laws 8 and 18, and the latter law, regarding the booty from wartime jousts and from tournaments, is dealt with separately below.

- Compensations, restor, etc. - Title XXV (comprising five laws) deals with the entitlement to compensation for death or injury, or loss of horses or equipment; to enable just compensation to be made, a detailed inventory of the appraised values of the horses and equipment shall be recorded before taking the field. ${ }^{50}$ Title XXVI Law 20 directs that once all the booty has been collected, first the king's share is deducted, and then the officers' compensations are paid. The rest is then divided.

- Division of the spoils - The remainder of Title XXVI, representing the bulk of the text, is preoccupied with the minutiae of guarding the spoils, ensuring a fair realisation of the value (by auction), and a fair distribution among all.

\section{IV.3. Tournaments and Wartime Jousts}

In what follows, I shall depart from Scott's translation of torneo as 'tournament', and instead use 'wartime joust' - 'tournament', understood as a peacetime organised competition, would be torneamiento, ${ }^{51}$ and 'wartime joust' fits better with the definition of torneo advanced in Title XXVI, Law 18: 'Torneo que se bolviesse de dos huestes que

been the English king's cut: Ayton, Knights and Warborses, pp. 127-37. The Byzantine practice reserved a sixth to the fisc: Settia, Rapine, p. 68.

${ }^{49}$ Las Siete Partidas 2:26:5 (pp. 95v-96r); Siete Partidas II (Burns), p. 477: 'skirmish, fight, foray, tournament [or rather 'wartime joust' - see below], predatory excursion, raid or ambuscade'. Scott's translations are open to debate, but the intent was evidently to imply a comprehensive listing, and distinctions, other than torneo, are not relevant for this article. See also Powers, Society Organized for War, pp. 153-59.

${ }^{50}$ Las Siete Partidas 2:25:4 (p. 94r); Siete Partidas II (Burns), pp. 471-72. These rules too have precedent in the fueros: Powers, Society Organized for War, pp. 167-72; Currie, Llibre dels Fets, pp. 48, 56; see also the English horse inventories and restauro equorum accounts for the time of the first three Edwards (1282-1364): Ayton, Knights and Warhorses, pp. 49-137; Swiss equipment records especially for the fourteenth and fifteenth centuries are also still in the archives: Schmid, 'Harnischrödel'.

${ }^{51}$ Barber and Barker, Tournaments, p. 91. 
estuuiesse vna cabo otra, o de los que tuuiesen cercado villa o castillo con aquellos que fuessen dentro'. 52

By way of differentiation, the same law defines the peacetime tournament proper: '.. torneamiento que se faze, por razon de vsar las armas e non por matarse, nin por otra enemistad, que los omes ouiessen vnos con otros'. ${ }^{53}$ In these 'friendly' jousts, there is no sharing of the booty and no obligation to pay the king's share; whoever takes ransoms depends on the agreed rules of the tournament, and there is a presumption that the winner of a joust will receive the horse of the vanquished. ${ }^{54}$ If it is a judicial duel, again the winner is solely entitled to the spoils. Since these are not strictly military situations, however, the subject shall not be further investigated. ${ }^{55}$

'Joust' can be understood as a lance-on-lance action in battle, as already suggested by William of Malmesbury, who writes of the battle of Lincoln 1141 that 'tentavere primo regii proludium pugnae facere, quod Justam vocant, quia tali periti erant arte'. ${ }^{56}$

In the cases of the predatory excursion and the wartime jousts, the spoils are not just exempt from the king's share, but each individual should keep what he won, without any obligation to share with anyone. The rationale given is that the individuals act on their commander's orders, and expose themselves to greater personal risk away from the safety of the army.

Along with the predatory excursion (espolonada), wartime jousts and tournaments proper present an interesting situation. There is a clear contradiction between Law 5 of Title XXVI, which explicitly says that the king's share is applied to spoils won in such events, and Law 18 of the same title, which says they are (mostly) exempt from the king's share. The contradiction is likely the result of different jurists drafting the different sections.

52 Siete Partidas II (Burns), p. 485: '[A] tournament [...] instituted between two armies arrayed against each other, or between the besiegers of a town or a castle and those defending it'; Las Siete Partidas 2:26:18 (p. 99r).

53 Siete Partidas II (Burns), p. 485: '... a tournament instituted for the purpose of practising arms, and not to kill or to indulge any enmity which men may entertain towards one another ...' - Scott translates both torneo and torneamiento as 'tournament'. Las Siete Partidas 2:26:18 (p. 99r).

54 Las Siete Partidas 2:26:18 (p. 99r); Siete Partidas II (Burns), p. 485.

55 Besides, the Iberian tournament has already received comprehensive treatment by Fallows, Jousting, though the focus of Fallows' research is on the fifteenth century and later.

56 'The royal (cavalry) attempted to conduct a prelude to the fight, which they call "joust," because they were experienced in this technique...': William of Malmesbury, Historia Novella, III $\$ 40 / 741$, p. 1423/n530; Barber/Barker, Tournaments, pp. 18-9; Verbruggen, Warfare, p. 34; Fallows, Jousting, pp. 256-57. 


\section{IV.4. Equipment Quality and Levels of Compensation}

Title XXV (comprising five laws) deals with compensation, mainly for injury or death suffered in action. ${ }^{57}$ However, the loss of animals (particularly horses and mules) and kit was also compensated (Law 4), and to ensure fairness, the laws required all animals and equipment to be appraised at the beginning of the campaign; this involved a considerable amount of clerical effort, but one evidently thought worthwhile since the prospect of fair compensation encouraged the fighters to put their high-quality equipment at risk. ${ }^{58}$

Another device to encourage fighters to present themselves well kitted out is in Title XXVI, Law 28: the better the fighter's equipment, the greater his share of the booty. ${ }^{59}$ A full share is (somewhat confusingly) called a canalleria. ${ }^{60}$ The passage also throws a

${ }^{57}$ Las Siete Partidas 2:25 (pp. 93r-94v); Siete Partidas II (Burns), pp. 470-73. The principle of compensation, and the concomitant rules, have precedent in the twelfth-century municipal militia charters: Powers, Society Organized for War, p. 27.

58 Las Siete Partidas 2:25:4 (p. 94r); Siete Partidas II (Burns), pp. 471-72; municipal militia organisation already included clerks tasked with record-keeping: Powers, Society Organized for War, p. 96. Similar records dating from the fourteenth and fifteenth centuries, known as Harnischrödel, are preserved in Swiss archives: Schmid, 'Harnischrödel'; Gassmann, 'Honour and Fighting', p. 142 The municipal militia charters of the late twelfth century allow a person bringing better equipment to nominate another person for exemption from service, or to gain exemption from service-related taxation; the desired effect was to have a smaller, but better equipped and more effective force: Powers, Society Organized for War, pp. 45, 124-26, and 174-76. In Switzerland as well, the authorities obliged the owners of kit who were not going to fight, including old men, landowning women, and widows, to lend the equipment they owned or were obliged to own to those who were going on campaign, and the Harnischrödel kept track of who gave what to whom, and how much it was worth: Schmid, 'Harnischrödel'.

59 Las Siete Partidas 2:26:28 (p. 102r); Siete Partidas II (Burns), p. 493 - Scott's translation here requires some attention, since he seems to read the law as rewarding a fighter for bringing the equipment in as booty. However, that conflicts with the express rationale stated in the first sentences of the law, the vocabulary in the original, and with the logic of the provisions. The challenge of persuading feudal levies to turn out in the kit desired by their commandants was not confined to Castile, as the Swiss experience also shows: Gassmann, 'Honour and Fighting,' p. 142. Fourteenth-century England used pay gradations for the same purpose: Ayton, Knights and Warborses, pp. 89-102. Reluctance to wear protective arms was a phenomenon already deplored in Vegetius' times (Book I. Cap XIX (pp. 15-16)).

60 There seems to be a distinction between a mounted man's share and an infantryman's share - it would not be logical for a mounted crossbowman to be entitled to the same share as his colleague on foot. A suggestion is found in the sentence dealing with the donkey, which entitles to merely half a peonia (translated by Scott, persuasively, as 'a foot-soldier's share'). However, so far as I can see, this is the only mention of peonia, and the shares of both the regular infantryman and the crossbowman on foot are defined in terms of caualleria. Possibly, the provision entitling anyone with a horse to half a caualleria is intended as an add-on, so that a minimally qualifyingly equipped mounted man would receive at least one-and-a-half times the share of a foot soldier. Even that 
light on the arms and armour of the time. ${ }^{61}$ Remarkably, the focus of the provision is on defensive arms. ${ }^{62}$

The Partidas helpfully offers a (partial) glossary of the terms: the loriga, or standard mail hauberk, is not explained, and is presumably a short-sleeved, thigh-length mail armour. ${ }^{63}$ A lorigon is a suit of armour where the sleeves come to the elbow, and do not reach the hand; a camisote is one where the sleeves extend to the hand. A guardabraco has sleeves.

The law's rules are here listed in full, as they provide an interesting glimpse of the arms and armour of the time as well as what combinations were considered sufficient protection; furthermore, Scott's translation is not always persuasive, and occasionally requires clarification. Note especially the horse loriga; both Christian and Muslim Iberian cavalry were early adopters of horse armour: ${ }^{64}$

- An individual mustering with horse, sword, and lance: entitled to one share.

- Horse's coat of mail (loriga de cauallo): an additional share. ${ }^{65}$

- Coat of mail complete with coif (loriga complida con almofar): one share. ${ }^{66}$

- Complete rerebraces (upper arm protection) which buckle on (brafoneras complidas, que se cingan): half share.

- Lorigon, shield and iron cap: one share. ${ }^{67}$

does not quite solve all problems, but the issue could not be satisfactorily resolved for this article. Further background to the terms with Lourie, 'Society Organized for War', p. 56.

See also Currie, Llibre dels Fets, pp. 50-51: The Mallorcan booty was divided into nearly 13,450 cabellerias, though here of land.

${ }^{61}$ See also Powers' review of the municipal charters' requirements for status-compliant mount, armament and equipment especially for aspiring caballeros: Society Organized for War, pp. 126-33.

62 This can also be observed in other contexts, e.g. the articles of the Bolognese societates armatae of the mid-thirteenth century: Gassmann, 'Bolognese Societates Armatae', pp. 212-13. Maybe what we are seeing is a medieval occupational health and safety concern; the levies were not professionals, and even if they were experienced, there is a parallel to modern safety equipment: it is cumbersome, and enforcing its use a constant command challenge, despite the obvious benefit to the individual.

${ }^{63}$ The will of Inés Rodríguez of Toledo, written in 1318, also includes a section on arms and armour; she also willed a lorigón, which is here explained as having shorter sleeves than a lóriga Martínez/Martínez, 'Inés Rodríguez', p. 50. Fallows, Jousting, on pp. 509-11, includes a glossary for late medieval and Renaissance sources; the meanings of some terms have obviously evolved. See also Powers, Society Organized for War, pp. 73-74 and 129-31.

${ }^{64}$ Nicolle, Medieval Warfare Source Book, p. 167.

${ }^{65}$ It seems to me that bringing mail horse-armour entitles to an additional share ('et por loriga de cauallo otra' [my emphasis]), not just a share, as Scott's translation implies.

${ }^{66}$ Almofar is translated by Scott as 'helmet.' With Martínez/Martínez, 'Inés Rodríguez', p. 50, an almohar is a mail coif to go underneath the helmet (casco); so also Nicolle, Medieval Warfare Source Book, p. 163. 
- Lorigon with sleeves that reach to the wrists, with rerebraces: one share.

- Camisote and perpunte (pourpoint, a quilted jacket or gambeson worn under the armour): one share.

- Guardabraços with pourpoint and iron cap: one share.

- Armour plates (fojas) with iron cap: one share. ${ }^{68}$

- Complete armour plates and extensive mail (fojas complidas co mangas fasta la mano, e lorigon fasta el cobdo, con faldas de loriga): one share. ${ }^{69}$

- Mounted crossbowman with his crossbow, with string and auancuerda, with his belt and quiver with a hundred quarrels or more: one share, and for his arms and horse as stated above. ${ }^{70}$

- Crossbowman on foot with his crossbow and full gear as defined: one share.

- Infantryman with spear: half share. ${ }^{71}$

- Horse, other riding or pack animal: half share.

- Donkey-like animals: half a foot soldier's share (media peonia). ${ }^{72}$

The commanding officer (cabdillo) is entitled to double his regular share, in addition to the special allocations mentioned elsewhere, and the same applies as a rule to the other officers (adalid). ${ }^{73}$

${ }^{67}$ In the original capillo de fierro; Scott translates it as 'steel cap.'

68 Also mentioned in Martínez and Martínez, 'Inés Rodríguez,' p. 50; see also next footnote.

${ }^{69}$ Hoja literally translates as 'leaf'; what is probably meant is a scale armour peculiar to Iberia: Nicolle, Medieval Warfare Source Book, p. 166. Full plate armour, as became current in the late fourteenth and fifteenth centuries, would be armadura de placas or arnés blanco.

70 Scott translates 'con cuerda e con auancuerda' as 'with both his strings.' Understanding this to mean 'with a spare string' does not make sense, since a crossbow, unlike a self bow, cannot be manually restrung. Possibly it refers to a string loop, needed to engage the latch with certain types of crossbow. Alternatively, it could refer to the cord needed for a cord-and-pulley spanning mechanism, or to a cord or thong suspended from the belt with the spanning claw attached, as would be necessary for spanning the crossbow while mounted; which would also explain why the belt (cinto) is expressly required - I am grateful to Jack Gassmann for this explanation. See PayneGallwey, The Crossbow, pp. 73-80. See also Settia, Rapine, p. 70, for Italian precedents.

71 The original says 'lança con dardo, o con porra'; Scott translates this as 'a lance, and a javelin, or a war-club.' However, it seems to me that the law specifies two different types of pole weapons, maybe an alternative between a pike and a plançon or goedendag, and not a spear or lance plus another weapon. Javelins anyway tend to be missile weapons for the mounted man, and used in number - a single javelin seems pointless.

${ }^{72}$ According to the gloss, a peonia is half a canalleria - Siete Partidas 2:26:28 (p. 102r). Allotting an infantryman half a mounted man's share seems to have been common: Settia, Rapine, p. 70.

73 See Law 14, same title: Las Siete Partidas 2:26:14 (p. 97v); Siete Partidas II (Burns), p. 482. 


\section{IV.5. The Tactical Function of Spoils Regulation}

The question of ransoms, booty, and spoils is certainly not absent from the witnesses of the time - and there is no dearth of instances, in fact or fiction, where disagreements over the division of the spoils cause strife. ${ }^{74}$ But apart from ransom as an aspect of the courtly tournament or battle ransoms, the administrative aspects of the question mostly receive short shrift in academic literature. ${ }^{75}$

Beyond the issues of income, effective regulation of the division of the spoils also has a tactical aspect - an army that focuses on plundering before the victory is secured may well endanger its success, as they are not attentive to an enemy rallying, and are in no position to resist should that happen. ${ }^{76}$ In Conradin's defeat at Tagliacozzo in 1268, for example, the Stauffen - commanded by Henry of Castile - were initially successful, but scattered to plunder, and so fell victim to the rallying forces of Charles I of Anjou. ${ }^{77} \mathrm{It}$ may be notable that Conradin's forces were a mixed bunch who may not have trusted in a fair distribution of the booty and so moved to secure what they could. By painstakingly laying out the entitlements and the process, the Siete Partidas provided all participants reassurance of a fair share, even if their orders took them away from the battlefield. ${ }^{78}$

\section{IV.6. Spoils, Largesse, and Arms}

Liberality is generally a mark of nobility, but while the king has the resources of his realm at his disposal (and his treasury benefits from a preferential $20 \%$ cut of the loot, over and above his prerogatives), the knight first has to earn what he gives away. This is

\footnotetext{
74 Some of Charny's demandes go precisely to this point, such as in the question whether it is acceptable for knights to refuse to fight on foot, as that would reduce their entitlement to the spoils (Forster, 'Geoffroy de Charny,' p. 213), or whether a sergeant who has captured a horse during battle is entitled to a mounted share (ibid., p. 215).

75 Keen, Chivalry, p. 154, acknowledges in passing that warfare is one of the acceptable ways to riches for the nobility (also Verbruggen, Warfare, pp. 49-51), but in other, much longer passages deals with the question of booty and spoils disparagingly - pp. 88-89, 229-33. France points to the importance of booty both in providing income to the individual to pay for arms and to the princely treasury (Western Warfare, pp. 3, 6, 71), but does not elaborate on the practicalities or procedures involved. On the other hand, Ayton (Knights and Warhorses, pp. 127-137, also fn 47 and 48) and Settia (Rapine, pp. 56-79) refer to the practices in fourteenth century England and in Italy respectively. Powers, Society Organized for War, pp. 162-87, affords the matter ample space, focused on the municipal militias' booty distribution.

${ }^{76}$ Explicitly in the pulcher tractatus, in a section not lifted from Vegetius (cap. 31 / pp. 61-62) - and quoting Al-Farabi. So also already in the Byzantine regulations, and a principle enforced by successful condottieri like Cangrande della Scala: Settia, Rapine, pp. 67-68.

${ }^{77}$ France, Western Warfare, p. 183; Settia, Rapine, pp. 58-59.

${ }^{78}$ Byzantine practice too included non-battlefield personnel: Settia, Rapine, p. 68.
} 
a recurring theme in Joanot Martorell's Tirant lo Blanc. ${ }^{79}$ His capacity to be generous is a direct result of his fighting prowess.

Some attention must also be paid to what is given: a lord giving his followers arms, armour, warhorses, or tack is not merely giving things of value but tools of the military trade that will make the recipient more effective by improving his equipment or enabling him to field more and better armed retainers (and the better they are equipped, the greater their booty entitlement). ${ }^{80} \mathrm{~A}$ modern officer being promoted to lead a larger unit is not made a gift of the additional materiel; the commander expects the officer to use the additional resources effectively, and so play a greater role in securing the next victory. Similarly, compensation for lost arms is not merely compensation for the value lost, but designed to restore the knight to his fighting effectiveness.

William Marshal grew rich through peacetime tournament winnings, but his biographer also highlights Marshal's first battle, where he proves himself resourceful and courageous. ${ }^{81}$ Marshal dictated his memoires in his eighties and the event would have happened in his late teens or early twenties, so it must have been seared in his memory.

At the feast after the victory, to which Marshal is acknowledged to have contributed, and in front of everyone, Marshal is still ridiculed by one of the senior knights because he not only failed to secure any spoils and so is unable to make gifts, but he lost the horse he had been given to boot. It is probably significant that the gift asked for is a minor strap from a horse harness. ${ }^{82}$ One must assume that Marshal's superiors did not feel that he deserved to be entrusted with more military kit, as he spent the next months in professional limbo until one of his old officers took pity on him and gave him another chance. ${ }^{83}$

By casting the issues of compensation and booty share into legislation, the Siete Partidas establishes a regime that seeks to be fair to all and promote military effectiveness, as exemplified by the provisions that also include in the booty-sharing units performing

${ }^{79}$ Joanot Martorell, Tirant lo Blanc; the parts focusing on the tournament, chapters 1-28, are Martorell's reworking of Guy of Warwick (dealt with by Price, 'Yron \& Stele') - Introduction, p. xi. Also Kaeuper, Chivalry, p. 196.

${ }^{80}$ Currie, Llibre dels Fets, p. 44. In the Templar Rule, warhorses, arms and armour go to the marshalcy, cash value spoils to the local commander: Règle du Temple, Rules 102, 116 / pp. 89, 98; Settia, Rapine, p. 69.

81 William Marshal, Introduction, pp. 2-4; Verbruggen, Warfare, p. 50; Keen, Chivalry, pp. 88-89; Bumke, Höfische Kultur, p. 371; Asbridge, Greatest Knight, pp. 124-26.

82 William Marshal, pp. 37-39; Asbridge, Greatest Knight, pp. 55-57.

83 William Marshal, pp. 39-41; Asbridge, Greatest Knight, pp. 57-63. 
militarily important functions away from the battlefield. Compensation and booty share are emphatically not a royal gift, but the legal entitlement of all fighting men. ${ }^{84}$

\section{IV.7. The Siete Partidas and Geoffroi de Charny's demandes}

In the context of the knightly imperative to win spoils, the privileging of wartime jousts provides a gloss on one of the more knotty demandes raised by Geoffroi de Charny in 1351; in his question G10 in the demandes pour la guerre, a cavalry squadron is patrolling outside the walls of a besieged city. The commandant has given the explicit order not to leave the formation. A mounted force of the besiegers sallies out and offers jousts, which some from the patrol take up, in defiance of their orders. The question is whether those from the patrol who lose their horses in the process should be entitled to restor. ${ }^{85}$

To the modern military mind, it seems bizarre that there would even be a question. Indeed, de Charny does not answer any of his demandes, and his response in this case may well have been no. But it is telling that for de Charny, the only issue open to debate is the granting of restor to the unhorsed. There is no question about punishing those who disobeyed, or depriving those who won spoils of their gains. ${ }^{86}$ Reading the two texts in conjunction, though, a three-part argument for restor comes to mind:

- Firstly, the commander of a knightly unit was essentially a primus inter pares; he held leadership, but not command, and may well have been socially inferior to the individuals nominally under him. ${ }^{87}$

- Secondly, a knight was under an imperative to win spoils; that the lord had to offer the opportunity for material gain was part of the equilibrium of a military constitution under which the knight was responsible for supplying his own horse, arms, armour, and retainers, was dependent on the income from spoils, and risked his life, limb, and property on behalf of the lord.

- Thirdly, the situation confronting de Charny's knights was an explicitly privileged one. By depriving the knight of the opportunity for gain, the

\footnotetext{
${ }^{84}$ Explicitly in Las Siete Partidas 2:26:9 (p. 97r): 'E porende los antiguos de España, pusieron, que sin aquel derecho que cada vno deue auer en su parte de la ganancia, que fiziessen que han primeramente, de auer emienda: e enchas de los daños: que ouiessen recebido...'; Siete Partidas (Burns), p. 480: 'Wherefore the ancient people of Spain ordained that, in addition to the right which each one should have to a share of the booty which he secured, all were first entitled to compensation for the injuries they had suffered...'. In style and content, Law 9 echoes the Decretum Gratiani, see fn 47.

85 Forster, 'Geoffroi de Charny', pp. 216-17.

86 Forster, 'Geoffroi de Charny,' pp. 216-17; the Siete Partidas refer to the commandant's orders, so a Castilian caballero might not have fared as well as de Charny's French knight.

${ }^{87}$ Etxeberria, 'liderazgo militar,' p. 655.
} 
commandant was, to some extent, violating the implied contract between the knight and the war-making lord, which in turn justified the demand for restor.

\section{SUMMARY AND OUTLOOK}

\section{V.1. Summary}

The Siete Partidas was compiled at a time when Alfonso X was faced with the task of consolidating the phenomenal gains made by his father, Fernando III. It forms part of a legislative programme that also encompassed the standardisation of fueros, the municipal charters that constituted the various towns' civilian government and militia organisation. Like so many attempts by medieval princes at imposing legislation, the Siete Partidas was a mix of restatement of the status quo, of justification of royal power and prerogative, and of not always successful programmatic ambition - the various feudatories defended their acquis tenaciously. ${ }^{88}$

\section{V.2. The Cities and Their Fueros}

As Powers shows, the city militias were an important military element in the Christian Iberian kingdoms' Reconquista, both in aggressive expeditionary warfare, as well as in the defence in depth of territory once conquered. The provisions in the Partidas regarding spoils, for example, largely reflect the tenor of the fueros, though the crown was also keen on slanting the rules to its benefit. But the cities also used their military might to jockey for power amongst each other, or in opposition to the crown. In the Partidas' passages on the promotion of commoner commanders to noble rank, or in the fuero provisions where the crown exempts city-resident knights from municipal militia service, the crown is clearly seeking to weaken the cities' nuisance value by securing the allegiance of the militarily important knightly class. ${ }^{89}$

\section{V.3. The Siete Partidas, Its Sources, and Influence}

For other subject matters treated in the Partidas, it is difficult to identify precedents the battlefield formations are a case in point. It is sometimes tempting to see a direct link, but on the basis of the current stage of research, the evidence is too tenuous and there are simply not enough unambiguous witnesses. Still, the provisions set out are eminently practical; they deal with the tools of command, military organisation, and

88 Powers, Society Organized for War, pp. 68-70; Panateri, 'Adaptar y sobrevivir'. See also Currie's description of James I of Aragon's travails in persuading his subjects to provide ships for the siege of Borriana: Llibre dels Fets, pp. 45-47.

89 Powers, Society Organized for War, p. 162; Lourie, 'Society Organized for War', p. 57. The Santa Hermandad was another device for the Crown to eventually undercut the cities' power: Stewart, 'Santa Hermandad'. 
equipment of the time. ${ }^{90}$ We can therefore confidently state that they were not antiquarian, and though the 'ancients' are, one may say, ritually invoked, there is very little evidence that the work's compilers uncritically lifted text from classical authors.

Whether it influenced later writers or practitioners is also hard to confirm; the Partidas can be recognised in battle descriptions from a variety of sources, and where it appears in other literature, such as in Giles of Rome, there are obvious parallels, but also too much difference to suggest a direct relationship. Either way, the provisions were in the mainstream of contemporary thought, so barring any direct evidence, attributing a formative influence on later writings must remain speculative. The obvious parallels do suggest, though, that there was a common military tradition.

This parallelism, however, does not necessarily imply textual transmission, and given the disparity in time and place of the witnesses, such transmission appears unlikely to have been the sole conduit, if at all. The knowledge must therefore have (also) been spread through two other, not mutually exclusive avenues: on one hand by word of mouth, as lore passed down from senior knights to junior knights and squires during their long years of education. ${ }^{91}$ On the other hand, knights tended to travel and attach themselves to various, geographically dispersed lords and rulers, and could have spread the knowledge in that way; coalition military ventures like the Crusades also offered a forum for the creation of an unité de doctrine.

The rules on distribution of spoils raise a different issue; the Siete Partidas sets out the relevant legislation for Castile - but did other realms have corresponding legislation, and if so, what were the rules? Were they reliably enforced? Rules obviously existed elsewhere; Andrew Ayton refers to the changing practices for fourteenth-century England and Aldo Settia refers to numerous sources for Italy, but does not find a consistent set of rules or practice. ${ }^{92}$ It would be interesting to see a more detailed comparison between rules.

\section{V.4. Mechanics for the Financial Aspects of Warfare for Its Participants}

Finally, the Siete Partidas highlights an aspect of medieval warfare that is rarely investigated in academic literature: while the centrality of the financial element of warfare, especially as it relates to the caballeros, the knights or lower nobility, as well as its fiscal aspects, is regularly remarked upon, the detailed mechanics receive little attention. The chansons may gloss over the grubby aspects of acceptable profiteering but as a legal

\footnotetext{
${ }^{90}$ Etxeberria, 'liderazgo militar,' p. 646.

${ }^{91}$ Etxeberria, 'liderazgo militar,' pp. 647-48.

92 Ayton, Knights and Warhorses, pp. 127-37; Settia, Rapine, pp. 56-79. Currie's description of the sharing of the booty following the fall of Mallorca suggests that things did not always go according to plan: Llibre dels Fets, pp. 57-58.
} 
and practical text, the Siete Partidas deals with it matter-of-factly and embeds it into a matrix of legal entitlements, distinctions, and administrative process.

This article has narrowly focused on selected provisions of the second Partida relating to land battles. The earlier titles of this Partida, which also receive more attention in modern academic literature, deal with royal government in general, with links to the status of knights treated in the titles referenced here. Naval warfare has been omitted from this article and there was not the space to discuss the Partidas' pronouncements on just war, or the off-battlefield tactical and organisational instructions, all of which have received relatively little notice. Also, on the basis that Iberian dynasties occupied numerous European thrones, and that Spanish armies were active across the continent, did the Siete Partidas leave any traces there? Considering the accessibility and practical relevance of the source, the comparative lack of attention is surprising.

\section{BIBLIOGRAPHY}

\section{VI.1. Primary sources}

Standard Monumenta Germaniae Historica abbreviations used

Annales Gandenses, in Annales Aevi Suevici, ed. by J. M. Lappenberg and G. H. Pertz, MGH - SS Vol. 16 (Hanover: Hahn, 1859), pp. 555-97

Decretum Gratiani (Rome: Populus Romanus, 1584)

Giles of Rome (Aegidius Romanus, Aegidius Colonna), De regimine principum (Venice: Bevilaqua, 1498)

van Heelu, Jan, Chronique en Vers de Jean van Heelu ou relation de la bataille de Woeringen, ed.

J. F. Willems (Brussels: Hayez, 1836)

Las Siete Partidas, ed. by Gregorio Lopez, vol. 1 (Salamanca: Andrea de Portonaris, 1555)

Lopes, Fernão, Chronica de El-Rei Dom João I, ed. by Luciano Cordeiro, vol. 5 (Lisbon: Escriptorio, 1897)

Martorell, Joanot and Martí Joan de Galba, Tirant lo Blanc, trans. by David Rosenthal (New York NY: Schocken, 1984)

Der pulcher tractatus de materia belli: Ein Beitrag zur Kriegs- und Geistesgeschichte des Mittelalters, ed. by Alfred Pichler (Graz-Vienna-Leipzig: Leuschner und Lubensky, 1927)

Règle du Temple, ed. by Henri de Curzon (Paris: Renouard, 1886)

Schürstab, Erhard, Beschreibung des Ersten Markgräflichen Krieges gegen Nürnberg, ed. by Josef Bader, (Munich: Georg Franz, 1860) 
Siete Partidas: Volume One: The Medieval Church: The World of Clerics and Laymen, ed. by Robert I. Burns, trans. by Samuel Parsons Scott (Philadelphia: University of Pennsylvania Press, 2001 $)^{93}$

Siete Partidas: Volume Two: Medieval Government: The World of Kings and Warriors, ed. by Robert I. Burns, trans. by Samuel Parsons Scott (Philadelphia: University of Pennsylvania Press, 2001)

Vegetius Renatus, P. Flavius, Flavii Vegetii Renati Viri Illustris de re militari (Cologne: Ceruicor, 1532)

William the Breton, Gesta Philippi Augusti, in Oeuvres de Rigord et de Guillaume le Breton, ed. by H. François Delaborde, Vol. 1, 276-7 (Paris: Renouard, 1882)

William Marshal (The History of): The true story of England's greatest knight, trans. by Nigel Bryant (Woodbridge: Boydell, 2016)

William of Malmesbury, Historia Novella, in: Patrologia Latina, ed. by J. P. Migne, vol. 179, 1391-440 (Paris: Garnier, 1899)

\section{VI.2. Secondary literature}

Allmand, Christopher, The De Re Militari of Vegetius (Cambridge: Cambridge University Press, 2011)

Asbridge, Thomas, The Greatest Knight (London: Simon \& Schuster, 2015)

Ayton, Andrew, Knights and Warhorses: Military Service and the Aristocracy under Edward III (Woodbridge: Boydell, 1999)

Barber, Richard, and Juliet Barker, Tournaments: Jousts, Chivaly and Pageants in the Middle Ages (Woodbridge: Boydell, 1989)

Bennett, Matthew, 'La Règle du Temple as a Military Manual or: How to Deliver a Cavalry Charge', in J.M. Upton-Ward, The Rule of the Templars: The French Text of the Rule of the Knights Templar (Woodbridge: Boydell \& Brewer, 1992), pp. 175-188

Bumke, Joachim, Höfische Kultur: Literatur und Gesellschaft im hohen Mittelalter (Munich: DTV, 1986)

Çeçen, Zeynep Kocabıyıkoğlu, 'Interpreting Warfare and Knighthood in Late Medieval France: Writers and Their Sources in the Reign of King Charles VI (1380-1422)' (unpublished doctoral thesis, Bilkent University, 2012) $<$ http://www.thesis.bilkent.edu.tr/0005061.pdf >

Currie, Colin, 'El rei-cavalleresc: Chivalry, Crusade and the Conduct of War in James I of Aragon's Llibre dels Fets' (unpublished master's thesis, Glasgow University, 2015) < http://theses.gla.ac.uk/7115/1/2015curriemphil.pdf >

93 The introduction includes a historical section by Joseph F. O'Callaghan (pp. xxx-xl) and a bibliographical note by Jerry R. Craddock (pp. xli-xlviii). 
Delbrück, Hans, Geschicbte der Kriegskunst: Das Mittelalter: Von Karl dem Großen bis zum späten Mittelalter (Hamburg: Nikol, 2008)

DeVries, Kelly, Infantry Warfare in the Early Fourteenth Century (Woodbridge: Boydell, 1996)

Domingues, José, 'A Tradição Medieval das Sete Partidas em Portugal', 7PartidasDigital. Edición crítica digital de las «Siete Partidas» 1 (2017), <https://7partidas.hypotheses.org/692> [accessed 16 October 2019]

Etxeberria Gallastegi, Ekaitz, 'El liderazgo militar en la Castilla del siglo XV', Hispania, 79 (2019), 639-68

Fallows, Noel, Jousting in Medieval and Renaissance Iberia (Woodbridge: Boydell \& Brewer, 2010)

Forster, Loïs, 'La place du cheval dans les traités de Geoffroi de Charny,' in Le cheval dans la culture médiévale, ed. by Bernard Andenmatten, Agostino Paravicini Bagliani, Eva Pibiri (Florence: Sismel, 2015), pp. 199-219

France, John, Western Warfare in the age of the Crusades, 1000-1300 (London: UCL, 1999)

García Fitz, Francisco, 'La didáctica militar en la literatura castellana (segunda mitad del siglo XIII y primera del XIV)', Anuario de estudios medievales, 19 (1989), 271-83

Gassmann, Jack, Jürg Gassmann, Dominique Le Coultre, 'Fighting with the Longsword: Modern-day HEMA Practice', Acta Periodica Duellatorum, 5/2 (2017), 115-33

Gassmann, Jürg, 'Honour and Fighting: Social Advancement in the Early Modern Age', Acta Periodica Duellatorum, 3/1 (2015), 139-81

—, 'The Bolognese Societates Armatae of the Late 13 ${ }^{\text {th }}$ Century,' Acta Periodica Duellatorum, 2 (2014), 195-231

Hosler, John D., 'Reframing the Conversation on Medieval Military Strategy', Journal of Medieval Military History, 16 (2018), 189-206

Guimarães, Marcella Lopes, 'Aljubarrota (1385) e as voces que fundam a lembrança', in Por São Jorge! Por São Tiago! Batalhas e narrativas ibéricas medievais, ed. by Marcella Lopes Guimarães, (Curitiba: Editora UFPR, 2013), pp. 121-56

Kaeuper, Richard W., Chivalry and Violence in Medieval Europe (Oxford: Oxford University Press, 1999)

Keen, Maurice, Chivalry (New Haven: Yale University Press, 2005)

Lourie, Elena, ‘A Society Organized for War: Medieval Spain’, Past \& Present, 35 (1966), 54-76

Martinez, Gilles, 'La méthode expérimentale appliquée à l'étude du geste guerrier:

l'exemple des formations collectives d'infanterie du Moyen Age central $\left(\mathrm{XI}^{\mathrm{e}}-\mathrm{XIII}{ }^{\mathrm{e}}\right.$ siècles)', in Expérimenter le maniement des armes à la fin du Moyen Age / Experimente zur Waffenhandhabung im Spätmittelalter, ed. by Daniel Jaquet and Nicolas Baptiste (Basel: Schwabe, 2019), pp. 57-72 
Martínez Carrillo, María de los Llanos, María Martínez Martínez, 'Un ejemplo de mozarabismo toledano: la familia de Inés Rodríguez (ss. XIII-XIV)’, Anales Toledanos, 27 (2014), 35-74

Nicholson, Helen, Medieval Warfare: Theory and Practice of War in Europe 300-1500 (Basingstoke: Palgrave Macmillan, 2004)

Nicolle, David, Medieval Warfare Source Book: Christian Europe and its Neighbours (London: Brockhampton Press, 1996)

Nogales Rincón, David, 'La monta a la gineta y sus proyecciones caballerescas: de la frontera de los moros a la corte real de Castilla (siglos XIV-XV)', Intus-Legere Historia, 13 (2019), 37-84

Panateri, Daniel, 'Adaptar y sobrevivir: Estrategias textuales de estabilización sobre Partidas en el siglo XIV', in Circulación de ideas en la Antigüedad tardía y la Edad Media: Occidente y Oriente, ed. by Fernando Ruchesi (Resistencia : Instituto de Investigaciones Geohistóricas, 2020), pp. 169-82

- El discurso del rey: El discurso jurídico alfonsíy sus implicancias políticas (Madrid: Dykinson, 2017)

Payne-Gallwey, B ${ }^{\mathrm{T}}$, Sir Ralph, The Crossbow: Mediaeval and Modern, Military and Sporting (London: Holland Press, 1903)

Powers, James F., A Society Organized for War: The Iberian Municipal Militias in the Central Middle Ages, 1000-1284 (Berkeley and Los Angeles: University of California Press, 1988)

Price, Brian R., 'Yron \& Stele: Chivalric Ethos, Martial Pedagogy, Equipment and Combat Technique in the Early Fourteenth-Century Middle English Version of Guy of Warwick', Journal of Medieval Military History, 16 (2018), 159-88

Schmid, Regula, 'The Armour of the Common Soldier in the Late Middle Ages: Harnischrödel as Sources for the History of Urban Martial Culture', Acta Periodica Duellatorum, 5/2 (2017), 7-24

Settia, Aldo, Rapine, assedi, battaglie: La guerra nel Medioevo (Rome: Laterza, 2003)

Stadter, Philip A., 'The Ars Tactica of Arrian', Classical Philology, 73 (1978), 117-128

Stewart, Paul, 'The Santa Hermandad and the First Italian Campaign of Gonzalo de Córdoba, 1495-1498', Renaissance Quarterly, 28/1 (1975), 29-37

Taylor, Craig, 'English Writings on Chivalry and Warfare during the Hundred Years War', in Soldiers, Nobles and Gentlemen: Essays in Honour of Maurice Keen, ed. by Peter Coss and Christopher Tyerman (Woodbridge: Boydell, 2009), pp. 64-84

Verbruggen, J.F., The Art of Warfare in Western Europe During the Middle Ages, trans. by Sumner Willard and R. W. Southern, $2^{\text {nd }}$ Ed. (Woodbridge: Boydell, 1998) 